\title{
A Research on the Reform of College English Blended Teaching Mode under the Background of Educational Informatization
}

Lin Zhu ${ }^{a}$

Hainan College of Economics and Business, Gui Lin-yang Town, Haikou, Hainan, China

\begin{abstract}
Nowadays, the rapid development of information technology has increasingly penetrated into all walks of society and even people's lives. With the development of education informatization, traditional teaching can' $t$ meet the needs of talents in the new era. Developing a new teaching mode by integrating internet, big data and traditional teaching has become the main theme of contemporary education. This paper studies the connotation of educational informatization and Blended Teaching theory and puts forward the Blended Teaching mode of College English by improving teachers' informationized teaching ability, constructing the diversified teaching platform, and setting up informationized teaching resource base, adopting different teaching methods and strategies, so as to improve students' enthusiasm and autonomy in College English learning and enhance the effect of College English teaching.
\end{abstract}

\section{Introduction}

With the rapid development of computer, internet, big data and digital campus, information technology has increasingly penetrated into all walks of society and people's lives. At the same time, higher education has entered the era of educational informatization. In March 2012, the Ten-Year Development Plan of Education Informatization (2011-2020), issued by the Ministry of Education of China, puts forward that it is a strategic choice for the development of national education to promote the modernization of education through education informatization. The Thirteenth Five-Year Plan of Education Informatization issued in June 2016 points out that education reform should be strengthened by deepening the integration of information technology and education. In April 2018, the Ministry of Education officially promulgated Education Informatization 2.0 Action.

The College English Teaching Guidelines (2016) formulated by the College Foreign Language Teaching Steering Committee requires colleges and universities to strengthen the use of network teaching platform and the construction of online courses, and encourage teachers to make full use of the blended teaching modes of Microclass, Mooc and Flipped Classroom in teaching so as to fully integrate classroom teaching with web-based learning. With the deepening of teaching reform in colleges and universities, the influence of information technology on traditional education is gradually deepened. College English, as an important basic subject of higher education in China, is facing and experiencing the opportunities and challenges of informationized education as well as other subjects. How to deeply integrate college
English teaching with modern information technology, stimulate students' learning enthusiasm and autonomy, so as to effectively improve the teaching effect of college English is an urgent issue.

\section{The Connotation of educational informatization and blended teaching theory}

\subsection{The connotation of educational informatization}

Educational informationization originated in the late 1990s. The United States proposed the formulation of the "Information Superhighway" plan. With the deepening of the construction of the plan, the concept of "informationization of education" was put forward. Educational informationization contains two meanings: on the one hand, it refers to the training of talents in the information society; on the other hand, it means the application of information technology in education and scientific research.

\subsection{Blended teaching theory}

Blended Teaching or E-Learning is a new teaching mode which combines traditional classroom teaching with modern information technology. Scholars at home and abroad have done a lot of research on it. Among them, foreign scholar Franks (2002) pointed out that Blended Teaching combines classroom teaching with online teaching, integrates various teaching methods and

\footnotetext{
a Corresponding author: 469357548@qq.com
} 
teaching techniques, and maximizes students' learning autonomy and flexibility. Smith J and Alert Masier (2002) believe that giving full play to the advantages of Elearning or Blended Learning (network or digital learning) and combining pure technological environment with traditional learning (face to face) can not only play a leading role of teachers, but also improve students' ability of autonomous learning and problem solving. Margaret Driscoll (2002) proposed that Blended Teaching is a mixture of various networked technologies, teaching methods, in order to make learning and work in harmony. Colis (2001) believes that Blended Teaching is the combination of traditional teaching and online teaching, so that online teaching can become a natural extension of classroom teaching, and both teaching and learning can be free from time and space constraints.

Domestic scholar Zeng Xiangning (2017) proposed that the Blended Teaching mode is an effective teaching organization form which integrates task-based teaching, situational teaching, interactive teaching, micro-class teaching and cooperative teaching. Wang Ying (2006) pointed out that Blending Learning takes into account both teachers' teaching and students' learning during the teaching process, emphasizes the combination of teachers' leading role and students' subjective status, and promotes the harmony, unity and close relationship of teachers and students. Tian Fupeng and Jiao Daoli (2005) believe that Blended Learning combines the advantages of traditional learning methods with those of E-learning. It not only plays the leading role of teachers in guiding, inspiring and monitoring the teaching process, but also fully reflects the initiative, enthusiasm and creativity of students as the main roles in the learning process. He Kekang (2004) puts forward that the so-called Blended Teaching is to combine traditional teaching methods with network teaching methods. The purpose of this combination is not only to play the leading role of teachers in the teaching process, to play an inspiring and monitoring role, but also to fully mobilize students' initiative, enthusiasm and creativity in learning. According to Fu Gangshan (2004), Blended Learning is a mixture of various learning methods, learning media, learning content, learning mode, and learning environment.

With the continuous reform and development of teaching mode, Blended Teaching has developed into a mixture of various teaching methods and strategies, classroom teaching and online teaching, diversified teaching resources, and diversified teaching theories. Its core is to maximize the advantages of each factor. By this, teachers can give full play to their leading role in guiding, inspiring and monitoring teaching, and at the same time stimulate students' enthusiasm, initiative and creativity in learning.

\section{The reform and strategies of college English blended teaching model}

\subsection{Improve English teachers' ability of information technology}

With the rapid development of information technology and economy, traditional teaching failed to meet the needs of talents in the new era. Educational informationization has brought great challenges to teachers' teaching. With the extensive use of Internet and mobile communication technology, teachers and textbooks are no longer the only way for students to acquire knowledge, and classroom is no longer the only place for students to acquire knowledge. Rather than a monodrama, teachers have become curriculum designers, organizers of teaching activities, instructors and helpers of students' learning. With the help of internet, teachers reconstruct knowledge, enlighten students' wisdom, and cultivate students' innovative thinking and self-learning ability.

Teachers with the ability of information technology application is the fundamental guarantee for the smooth implementation of informationized teaching. It requires not only teachers to have systematic professional knowledge structure, teaching skills but also to master the necessary information technology. Schools should strengthen College English teachers' training. Firstly, teachers should be encouraged to study teaching theories and methods, improve their knowledge structure, enhance the ability of resource selection, integration and teaching innovation. Secondly, all teachers should take part in the training of information technology to ensure that each of them is able to use basic teaching technology software, and master the basic skills of making teaching resources. For example, teachers can use PowerPoint, Prezi and Focusky to make courseware, and use Camstasia Studio to record and edit video. In addition, teachers should be able to smoothly implement teaching tasks through various network teaching platforms, in order to carry out teaching objectives, and effectively improve the effectiveness of College English teaching.

\subsection{Creating diversified teaching platform and informationized teaching environment}

A good information is necessary for carrying out the college English Blended Teaching mode.

Colleges and universities should strengthen the construction of digital campus, build a diversified teaching platform, and network teaching environment. By constructing the On-line and Off-line informatization teaching environment, college English teaching can break the geographical and spatial constraints, change the traditional closed teaching environment and single learning mode in the past, create a relaxed and pleasant learning atmosphere, provide more opportunities for selflearning and personalized learning space, so that students have greater selectivity and self-learning in the learning process. Students can make full use of fragmented time for learning, and then stimulate their enthusiasm and autonomy, so as to enhance students' comprehensive English ability.

\subsection{Constructing college English informationized teaching resource base}

Throughout our country, traditional college English 
teaching materials mainly consist of paper textbooks and reference books, some of which are equipped with CDROMs, or PPT courseware, but still there are great limitations for students to master the basic skills of listening, speaking, reading and writing.

Integrating "online" and "offline" resources and building informationized teaching resource base of College English are beneficial to both teachers' teaching and students' learning. With various resources of teaching videos, animations, movies and television, teachers can combine or extend the content of textbook with online resources, and present teaching situations through Microclasses, MOOC or Flipped Classeroom, so as to stimulates students' enthusiasm and autonomy in learning and help them learn better.

\subsection{Developing blended teaching mode}

By adopting Blended Teaching methods, and with the help of multiple platforms and teaching resources base, College English teaching can be improved effectively.

\subsubsection{Setting up "MOOC + Flipped Classroom" teaching mode}

MOOC, Massive Open Online Course, was proposed by Canadian scholar Dave Cormier and Bryan Alexander in 2008. In 2011, a free online course offered by Stanford University attracted wide attention, and subsequently set off a trend of MOOC. In 2012, many top universities in the United States, including Harvard University, Stanford University, Massachusetts Institute of Technology, set up new online learning platforms, which are free to learners all over the world through the Internet. The most famous platforms are Coursera, edX and Udacity. With the establishment of these learning platforms, MOOC has developed rapidly. China's famous universities also joined these platforms, such as Tsinghua University and Peking University have joined Edx, Fudan University has joined Coursera. Subsequently, more and more colleges and universities began to implement MOOC teaching.

With "MOOC + Flipped Classes" teaching mode, College English teaching is no longer limited by the number of students, teaching time, classroom or textbook. Students can make full use of their fragmented time, select appropriate materials from the online resource base and complete online learning at anytime, anywhere as they like.

\subsubsection{Constructing "Micro Course + Flipped Classroom" teaching mode}

"Micro Course" teaching is to present a knowledge point or a question with video. The video of "Micro Course" lasts usually 5-15 minutes, which has the characteristics of clear theme, short and concise.

When adopting "Micro Course + Flipped Classes" Teaching Mode in College English teaching, teachers should redesign the curriculum content, make small videos, and integrate the flipped classes through microcourse videos with the help of teaching platform, software and information resource base. The flip of content enables students to preview the content through watching videos on teaching platform before class, and to interact with teachers and classmates through messages on the platform or feedback, so as to get the guidance of teachers, thus gives full play to the status of teacher-led and studentcentered.

In addition, with the help of various teaching platforms, software and information resource base, teachers can redesign micro-course teaching section and difficult poins according to students' professional and English levels, so as to meet students' individual needs.

\subsubsection{Making full use of teaching platforms and intelligent mobile electronic terminal equipment to assist teaching}

Teachers can use diversified teaching platforms and mobile electronic terminal devices to assist teaching, such as Blue Ink Cloud Class, Pigai Network, School Curriculum Center, Baicichou, Love Reading, Online English Listening Broadcasting etc. Students can visit them and begin their study at any time and anywhere. Movies, animations, and games can greatly mobilize students' enthusiasm for participation, so that students can complete dull grammar, vocabulary learning in a relaxed game situation, and obtain knowledge from fun.

\subsubsection{Constructing a diversified teaching evaluation system}

Constructing a diversified teaching evaluation system is an important part of College English teaching reform. The process assessment should be strengthen in college English teaching. The diversified evaluation model "formative evaluation + summative evaluation" which based on information technology should be adopted in order to improve the teaching quality of College English. Specifically, online evaluation and offline evaluation are organically combined. Online assessment is based on formative assessment, and students' learning process is recorded by data. Offline assessment includes formative assessment and summative assessment, which are recorded by teachers and students group leaders. The evaluation includes team work performance, personal performance, attendance, pre-class preview, after-class review, brainstorming, homework, online course video resource learning, testing, mobile APP software learning etc. Assessment and feedback of teaching is an important part in the implementation of the Blended Teaching model of College English. It facilitates teachers to make timely adjustment and supplement. At the same time, the diversified teaching evaluation system is more flexible, which can stimulate students' learning enthusiasm, and is conducive to complete the teaching tasks.

\section{Conclusion}

In order to keep up with the trend of the times and cultivate high-quality talents, we should intensify the teaching reform. Adopting college English Blended 
Teaching mode, making full use of information technology, intensify the integration of information technology and teaching is an effective way to give play to students' enthusiasm and initiative and improve college English teaching effectively.

\section{Acknowledgement}

This research was financially supported by the China Institute of Higher Education Vocational and Technical Education Branch (Research on Strengthening Sinoforeign Cooperation in Running Schools in Higher Vocational Colleges and Improving the Quality of Talents Training, GZYYB2018147) and Hainan College of Economics and Business.

\section{References}

1. Zhu Binyan, Liu Shixiang. Construction of College English Hybrid Teaching Model Based on MOOC Vision. Extracurricular Education in China, 2016, 11.

2. Qiao Yutao. A Research on the Reform of Practice of College English Mixed Teaching Under the Background of "Internet + ". Modern communication, 2017.
3. Yang Jinfeng. A Study on the Promoting Role of Mixed Teaching in College English Teaching. Innovation Education, 2017.

4. Liang Kun, Hu Yan. A Study on the Application of Mobile Learning in Universities under the Background of Education Informatization. Journal of Inner Mongolia Agricultural University (Social Science Edrion), no.3, 2017.

5. Che Linhua, Zhao Jian. A Preliminary Study on the Construction of the Mixed Teaching Model of College English. Journal of Educational Institute of Jilin Province, vol.28, 2012.

6. Mo Guotao, Wang Liqiu. A Research on the Application of Mixed Teaching Model in College English Teaching. Science and Technology Innovation HeraId, 2017.

7. Zhao Jian. A Preliminary Study on the Construction of the Mixed Teaching Model of College English. Success (Education), 2012.

8. Hao Liqun, Chen Wentie. A Study on the Mixed Teaching Model of College English Listening Based on the Concept of Flipping Classroom. Modernization of Education, 2018.

9. Guo Xin. A Study on the Mixed Teaching Model of College English Based on Course Mourning under the Background of University Residence. Journal of Kaifeng institute of education, 2018. 